\title{
AUTHOR/TITLE INDEX TO VOLUME 2 (1982)
}

Bolling Beimesch, B.K., Organizational structure and its impact upon information management

Calendar of Events

Conference Report: ASIDIC

$63-70,128-136,343-350$

Editorials

$1,71-72,149,291$

Gait, J., A coordination and information center for a research-oriented computer communications network

Hickman, F.M. and J.D. McInerney, Needs assessment on education for knowledge utilization in the life sciences

ISU Interview

Maurer, H.A. and I. Sebestyen, 'Unorthodox' videotex applications: teleplaying, telegambling, telesoftware and telecomputing

Maurer, H.A., W.D. Rauch and I. Sebestyen, Some remarks on energy and resource consumption of new information technologies

McInerney, J.D.: see Hickman, F.M.

Methlie, L.B. and A.M. Tverstøl, External information services: a survey of behavioral aspects of demand

Mullen, A., Private files-a critical assessment

News, Trends and Comments

Rauch, W.D:: see Maurer, H.A.

Sebestyen, I.: see Maurer, H.A.

Sebestyen, I., Perspective of policy development in the field of informatics: the example of videotex technology

Tverstøl, A.M.: see Methlie, L.B.

United Nations Centre on Transnational Corporations, Transborder data flows: Access to the international on-line data-base market (Special Combined Issue)

Weteringh, C. van de, From card-tray to resource management: the influence of computing on information processing in a large international company 